\title{
Developing Supporting Reading Materials for English Subject
}

\author{
Nur Hidayat ${ }^{1}$, Slamet Setiawan ${ }^{2}$ \\ ${ }^{1}$ nurhidayat@stkipbim.ac.id; ${ }^{2}$ slametsetiawan@unesa.ac.id \\ ${ }^{1}$ STKIP Bina Insan Mandiri, Indonesia \\ 2Universitas Negeri Surabaya, Indonesia
}

Received: 11 May 2020 Accepted: 28 May 2020

DOI: 10.24256/ideas.v8i1.1335

\begin{abstract}
The objective of this study is to develop a supporting reading material for junior high school of grade seven based on Curriculum 2013 in Indonesia. The product of this research was a supporting reading material in the form of software and CD to support the main course-book. The instructional design was used the research and development (R\&D) model proposed by Branch which was popular as ADDIE (analyze, design, develop, implement and evaluate). It consisted of five steps; (1) analyzing, (2) designing, (3) developing (4) implementing, (5) and evaluating. The participants of product try-out were 30 students and 3 teachers of an Islamic junior high school in Gresik. To validate the product, the reviews of experts, students, and English teachers were provided. The result showed that supporting reading material was accepted and appropriate for the students grade seven in junior high level. It also motivates the students to learn English more and improve their reading skill.
\end{abstract}

Keywords: development, supporting material, reading achievement, junior high.

\section{Introduction}

The development of technology in education affects the teaching-learning process in the classroom. The combination of technology and face-to-face strategy (blended learning) in educational level becomes popular. Many studies of blended learning have been done by many researchers Barr, Leakey \& Ranchoux, 2005; Chenoweth \& Murday, 2003; Chenoweth, Scida \& Saury, 2006; Green Youngs 2001). It is able to improve students' achievements in academic (Abidoye, 2015; Francis, R. \& Susan, 2013; Hidayat, 2017; Lim \& Morris, 2009; Simpson \& Anderson, 2009) and intensifies students' motivation in teaching-learning process (Bahrain, 2011; Banados, 2006; Chang et al, 2008; Fidaoui, Bahous \& Bacha, 2010; Grgurovic, 2011; Hung 2015; Liou, Yang \& Chang, 2011; Romeo, 2008; Stracke, 2007; Wichadee, 2017). 
The development of technology in education influences the materials used in the teaching-learning process. E-book, online resources and other applications are used as material or supporting materials as the utilization of technology in teaching-learning. The use of e-book in teaching-learning gives positive effects on students' academic achievement (Tonkery, 2010; Rieders, 2011; Brown, 2012; Dixon, 2012). Other studies report that the utilization of electronic reading platform has a positive correlation to students' reading comprehension (Horne, 2012; Ciampa, 2012; Brown, 2012; Huang et al., 2012).

Reading is one of the essential English skills that should be mastered by English foreign language learners (EFL). By learning reading, they can add much information and vocabulary to support their English ability. It increases their knowledge and insight in other fields. The combination of technology in reading class supports the students in comprehending reading. Huang and Hong (2015) report that a flipped classroom is able to intensify the students' ICT and reading comprehension significantly. The application of technology (online learning) also provides a positive effect on students reading comprehension (Banditvilai, 2016; Dreyer and Nel, 2003; Levine et al, 2000; Sun, 2014; Tsai and Talley, 2014; Yang et al, 2014). However, many Indonesian EFL learners have low interest in reading therefore they encounter various problems outside the academic environment as a consequence of reading deficiency. It is affected by learning materials that are not balanced in covering all skills (Aratusa, 2018; Hidayat, 2017). According to Hidayat (2017) states that materials in English book of junior high school of Curriculum 2013 in Indonesia need to be revised or supported by other materials because the reading portion in it is not balanced with other skills and there is no vocabulary list in every chapter whereas vocabulary is the basic foundation of reading. To intensify students' ability in reading, the teachers need supporting material to solve those problems.

Research questions:

1. How are the procedures in developing supporting reading materials for English subject of junior high school level?

2. Do the supporting reading materials are relevant as the materials of junior high school level?

3. Do the supporting reading materials provide positive effect for the EFL learners of junior high school? 


\section{Method}

The Instructional design of this study modified the research and design model by Branch (2009). Branch (2009) developed ADDIE (analyze, design, develop, implement and evaluate) approach. It consisted of five steps; (1) analyzing, (2) designing, (3) developing (4) implementing, (5) and evaluating. The aim of this research was developing supporting reading materials to improve students' reading ability in junior high school level. The product of this study was supporting reading material for seven grade of junior high school for curriculum 2013. The objective of this study was to explain the process of developing supporting reading materials for seven grade of junior high school level to improve students' reading comprehension.

The research was held in East Java, Indonesia. The participants of this study were 3 English teachers and 30 EFL learners of one of Islamic Junior High Schools in Gresik. To validate the development of the supporting materials, the researchers involved two experts in the field of learning multimedia and content material of English learning and two English teachers as vice from the school. The researchers also implicated students and English teachers to complete the supporting reading materials.

In this study, the researchers grouped the data into two groups: qualitative and quantitative data. The qualitative data were obtained from the results of open-ended questionnaires (needs analysis), the results of material reviews by experts, students, and teachers (suggestions). The quantitative data covered the experts' scores of the product, students' and teachers' questionnaires about the product and students' scores.

In this study, the researchers used some instruments to collect data such as questionnaires, product judgment rubric, and product review. The researchers used open and close-ended questionnaires for the need analysis and students' and teacher's responses. The product judgment rubric was given to the expert to rate the product and gave suggestions. Product reviews were obtained from the students' and English teacher's suggestions.

In analyzing the data the researchers grouped the data into qualitative and quantitative data. The qualitative data consists of needs analysis questionnaires (openended) and reviews (suggestions from the experts, students, and teachers). The researchers collected all the questionnaires, reviews and observation notes and transcribed all into the writing form. The quantitative data consists of the results of the 
product review by experts (scores of the product) and students', teachers' questionnaires about the product. The researchers analyzed them and grouped them based on the classification. Last, the researchers analyzed and compared the result from the qualitative and quantitative data, and then the researchers made the conclusion.

\section{Results}

There were five steps in the process of developing the product of this study. These procedures are adopted from Branch (2009) design in product development. The first step in developing this project was analyzing the situation and condition to identify the students' and English teachers' needs. The method that was used by the researchers to select the material was distributing the questionnaires to the English teachers and the students to find out their difficulties and interest in teaching and learning English.

The first aspect that researchers did was gave questionnaires to students and English teachers to obtain information about students' and teachers' needs. The results of them were presented in table 1.

Table 1. The Need Analysis Result

\begin{tabular}{ccc}
\hline No & Students' Needs & Teachers' Needs \\
\hline 1 & Portable dictionary & Portable English Media \\
\hline 2 & Motivational English games & Reading materials \\
\hline 3 & Interesting reading materials & Interactive Media \\
\hline 4 & Vocabulary list with meaning & English Flash Game \\
\hline
\end{tabular}

From table 1 can be confirmed the students' and teacher's needs consisted of four aspects; media, materials, games, and dictionary. From the analysis above the researchers created supporting reading materials that covered all of those needs. Second, the researchers designed the product. In designing the product, the researchers took the English syllabus as the foundation of material content. The English syllabus was based on the curriculum 2013 that has been distributed by the Indonesian government. In this step, the researchers classified into two parts; constructing and designing materials. In constructing the materials, the researchers combined English reading materials from many resources based on the syllabus and the English teacher suggestion. It composed of English video, reading texts, English dictionary, activities, vocabulary list with the meaning, test items and feedback, and games. In designing materials the researchers used some programs such as; AutoPlay Media Studio, Button Shop, Wondershared Quiz Maker, Microsoft PowerPoint, and Cambridge Advanced 
Learners' Dictionary-3 ${ }^{\text {rd }}$ Edition. The appearance of product design was shown in Appendix 1.

Third, the researchers developed the material. The researchers combined all of the materials using Autoplay Media Studio 7.0 software to make it in the form of software or $\mathrm{CD}$. The researchers also wrote the procedure in operating it to make sure that the learners were able to operate it easily.

The fourth step was implementing process; the researchers did product try out and revision. The design of try out was started from the materials constructed by the researchers. Those materials were given to the experts to get judgments, suggestions, and comments from them. The experts were two people who have the capacity in learning multimedia and content material of English learning. The judgments, suggestions, and comments from the experts became standard to revise the materials. After that, the researchers revised the materials, then delivered them to the large group which consists of 30 students of grade seven of junior high school who represented three levels of ability (good, average, poor). Those materials also gave to the English teachers. The researchers also gave questionnaires to the students and the English teachers. The purpose of this activity was to obtain comments and responses from them. The students' and teacher's comments and responses became the basis of the second revision of the materials. After doing the second revision, the researchers gave the materials again to the experts to make sure that those materials were fixed. The design of try out can be seen in diagram 1 


\section{TRYOUT DESIGN}

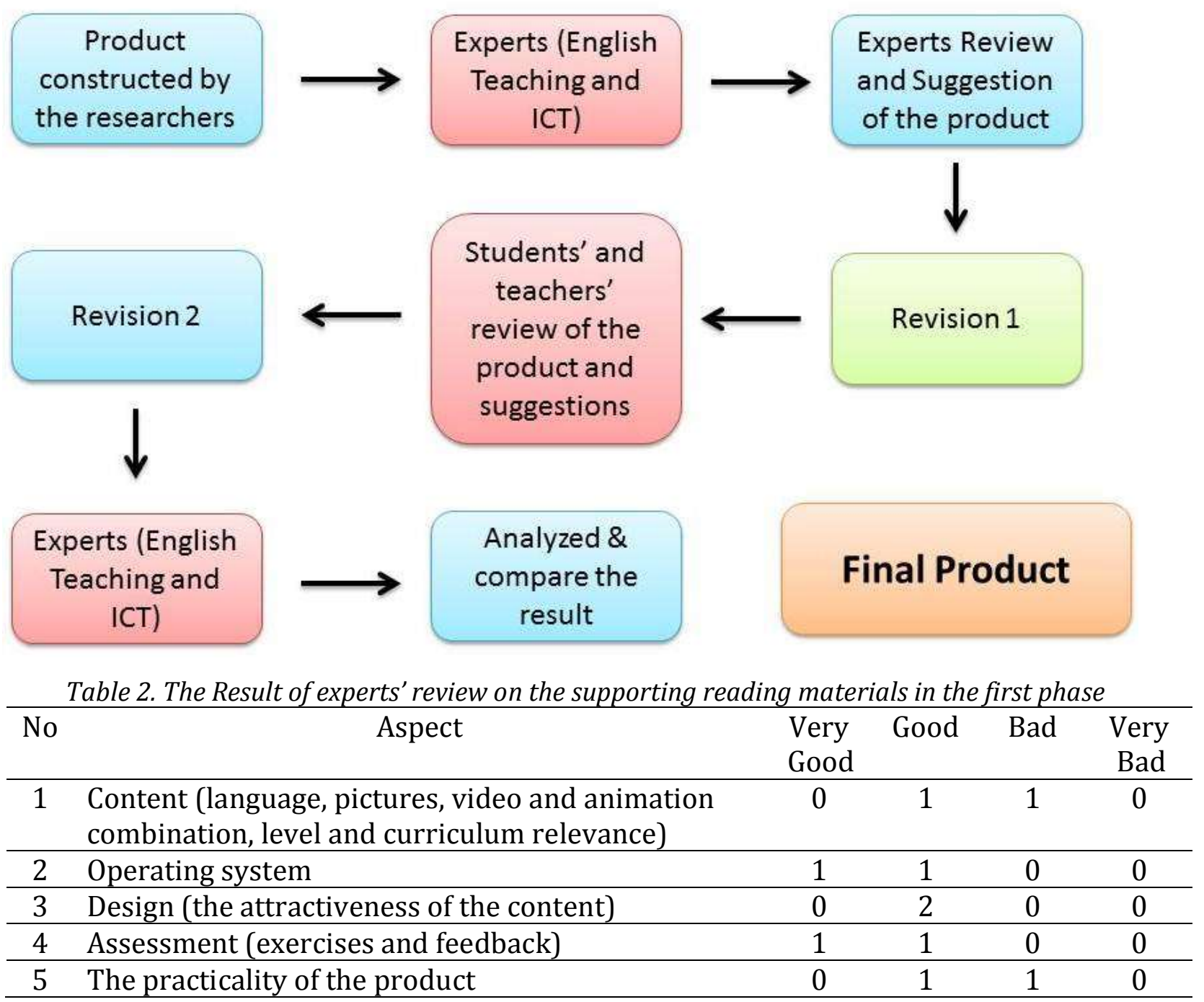

Based on table 2, both experts gave variant scores for the product and they gave suggestions also to improve the product. The experts' suggestions were presented in table 3 .

Table 3. The Experts' Suggestion in the first phase

\begin{tabular}{cl}
\hline No & \multicolumn{1}{c}{ Suggestion } \\
\hline 1 & The explanation of the way to operate the product was not clear enough \\
\hline 2 & The music background should be related to students' age \\
\hline 3 & The grammatical mistake must be revised \\
\hline 4 & Some exercises are too easy \\
\hline 5 & Some navigations in the product are too difficult \\
\hline
\end{tabular}


Based on Table 3, 5 elements should be revised to improve the product. The researchers revised the product based on the experts' suggestions and delivered the product to the experts again to get the experts' reviews about the product.

Table 4. The result of experts' review on the supporting reading materials in the second phase

\begin{tabular}{clcccc}
\hline No & \multicolumn{1}{c}{ Aspect } & $\begin{array}{c}\text { Very } \\
\text { Good }\end{array}$ & Good & $\begin{array}{c}\text { Bad } \\
\text { Very } \\
\text { Bad }\end{array}$ \\
\hline 1 & $\begin{array}{l}\text { Content (language, pictures, video and animation } \\
\text { combination, level and curriculum relevance) }\end{array}$ & 1 & 1 & 0 & 0 \\
\hline 2 & Operating system & 1 & 1 & 0 & 0 \\
\hline 3 & Design (the attractiveness of the content) & 2 & 0 & 0 & 0 \\
\hline 4 & Assessment (exercises and feedback) & 1 & 1 & 0 & 0 \\
\hline 5 & The practicality of the product & 1 & 1 & 0 & 0 \\
\hline
\end{tabular}

Table 4 posited that the experts gave a good and very good score for the product. It meant that the product was good and it was ready to do the tryout.

In product try-out, the researchers implemented the product in the teachinglearning process in the English class of a junior high school in East Java. The implementation of the product to the participants was defined in table 5:

Table 5. The Procedure for Implementing the Product

Meeting The Activities

Meeting 11 1. Students introduced to the product and how to operate it.

Introduction 2 . The researchers give the product to the students and ask them to use it in their homes.

Meeting 2 to 5 Inside Class

Product 1. The teachers ask the students to explain what they got from Implementation the product.

2. The students discuss it with their group and present what that they got from the product in the classroom.

3. The teacher gives feedback.

Meeting 2 to $5 \quad$ Outside the classroom

Product Implementation

1. The students use the product and answer the quiz in their homes.

2. The students play games on the product.

Meeting 6

1. Giving questionnaires to students and teachers.

After did all activities above the researchers delivered the product review scale to the English teachers and the students to get the students and teacher responses about the product. The product reviews were in the form of the Likert scale. The result of the product review presented in Tables 6 and 7.

Table 6. The result of Teachers' Product Review 


\begin{tabular}{|c|c|c|c|c|c|}
\hline No & Component & $\begin{array}{l}\text { Strongl } \\
\text { y agree }\end{array}$ & Agree & Disagree & $\begin{array}{l}\text { Strongly } \\
\text { disagree }\end{array}$ \\
\hline 1 & $\begin{array}{l}\text { The product attracts the students' } \\
\text { attention. }\end{array}$ & 2 & 0 & 0 & 0 \\
\hline 2 & $\begin{array}{l}\text { The product motivates the students in } \\
\text { learning English. }\end{array}$ & 1 & 1 & 0 & 0 \\
\hline 3 & $\begin{array}{l}\text { The combination of pictures, video, } \\
\text { animation, vocabularies, and content is } \\
\text { relevant to the topic. }\end{array}$ & 1 & 1 & 0 & 0 \\
\hline 4 & The content organization is good. & 1 & 1 & 0 & 0 \\
\hline 5 & $\begin{array}{l}\text { The appearance of the product was } \\
\text { good. }\end{array}$ & 1 & 1 & 0 & 0 \\
\hline 6 & The product runs well. & 1 & 1 & 0 & 0 \\
\hline 7 & $\begin{array}{l}\text { The content of the product is relevant } \\
\text { to the students' level. }\end{array}$ & 2 & 0 & 0 & 0 \\
\hline 8 & $\begin{array}{l}\text { The product improves students' ability } \\
\text { in English (especially reading skill). }\end{array}$ & 1 & 1 & 0 & 0 \\
\hline
\end{tabular}

Table 7. The result of the Students' Product Review

\begin{tabular}{|l|l|l|l|l|l|}
\hline No & \multicolumn{1}{|c|}{ Component } & $\begin{array}{l}\text { Strongly } \\
\text { agree }\end{array}$ & Agree & Disagree & $\begin{array}{l}\text { Strongly } \\
\text { disagree }\end{array}$ \\
\hline 1 & The product attracts your attention. & 17 & 13 & 0 & 0 \\
\hline 2 & $\begin{array}{l}\text { The product motivates you in } \\
\text { learning English. }\end{array}$ & 25 & 5 & 0 & 0 \\
\hline 3 & $\begin{array}{l}\text { The combination of pictures, video, } \\
\text { animation, vocabularies, and content } \\
\text { is relevant to the topic. }\end{array}$ & 20 & 10 & 0 & 0 \\
\hline 4 & $\begin{array}{l}\text { The content organization is good. } \\
\text { The appearance of the product was } \\
\text { good. }\end{array}$ & 23 & 7 & 0 & 0 \\
\hline 6 & $\begin{array}{l}\text { The product runs well. } \\
\text { The content of the product is relevant } \\
\text { to your level. }\end{array}$ & 14 & 12 & 0 & 0 \\
\hline 8 & $\begin{array}{l}\text { The product improves your ability in } \\
\text { English (especially reading skill). }\end{array}$ & 19 & 11 & 0 & 0 \\
\hline
\end{tabular}

Tables 6 and 7 clarified that the product was good and relevant to the students' level. The product motivated students to learn English. It also had good content, organization, and appearance. Moreover, it improved students' ability in English especially reading skill.

To improve the product to be better, the researchers asked the English teachers and the students to delivered suggestions about it. The students' and English teachers suggestions presented in table 8: 
Table 8. The Students \& Teacher Suggestion about the Product

\begin{tabular}{clc}
\hline No & \multicolumn{1}{c}{ Students suggestions } & Teachers Suggestions \\
\hline 1 & Adding more games' variant. & Adding more fonts variant \\
\hline 2 & Adding more background music. & \\
\hline
\end{tabular}

Those suggestions from the students and English teachers above were done by the researchers. These become the final revision of the product. After revised it, the product was analyzed and compared with all the data to make sure that the product was good and improved students reading achievement. Finally, it was fixed as a final product.

In the fifth, evaluation process, the researchers analyzed the results of the product. From all processes and the result above, the researchers concluded that the product was received as supporting materials to improve students' reading achievement. This product was in the form of software and CD interactive, so it involved a computer to operate it. It meant that the use of this product included in blended learning. The result above showed that the use of the product gave positive effects to the students. The students agreed that the product motivated them and improve their achievement. It was shown from the students' responses to the product. The English teacher also concurred that the product attracted students' attention, increased students' enthusiasm in learning English and develop their reading skill. It in line with Horne (2012), Ciampa (2012), Brown (2012) and Huang et al. (2012) reported that the use of electronic reading materials had a positive correlation to students' reading comprehension. Similarly, Tonkery (2010), Rieders (2011), Brown (2012), and Dixon (2012) believed that the electronic book gave a positive effect on students' achievement. Moreover, the combination of technology and face-to-face strategy also developed students' achievement (Abidoye, 2015; Francis, R. \& Susan, 2013; Hidayat, 2017; Lim \& Morris, 2009; Simpson \& Anderson, 2009) and students' motivation in the teaching-learning process. (Bahrani, 2011; Bañados, 2006; Chang, et al, 2008; Fidaoui, Bahous \& Bacha, 2010; Grgurović, 2011; Hung 2015; Liou, Yang \& Chang, 2011; Romeo, 2008; Stracke, 2007 Wichadee, 2017). Finally, the final product or supporting reading material was fixed.

\section{Conclusion}

From all explanation above, the researchers concluded that there were five steps in the process of developing supporting reading materials based on Branch (2009): (1) analysing, (2) designing, (3) developing (4) implementing, (5) and evaluating. All of 
those steps was done by the researcher in this study. The researcher also found that the supporting reading material was accepted and relevant for the English students of Junior high school in grade seven. The product increased students' enthusiasm for learning English. It also brought them enjoying the teaching-learning process in the classroom. Moreover, the product was acknowledged by the students and English teachers that it improved students' reading achievement.

\section{REFERENCES}

Abidoye, J. A. (2015). The effect of blended learning instructional approach on secondary school students academic achievement in geography in Akure, Ondo State, Nigeria. Research Journal of Educational Studies and Review, 1(5), pp. 106-110.

Bahrani, T. (2011). Computer-assisted language learning-some aspects. Language in India, 11(9), 271-278.

Bañados, E. (2006). A blended-learning pedagogical model for teaching and learning EFL successfully through an online interactive multimedia environment. CALICO Journal, 23, 533-550.

Barr, D., Leakey, J., \& Ranchoux, A. (2005). Told like it is! An evaluation of an integrated oral development project. Language Learning \& Technology, 9(3), 55-78.

Brown, R. (2012), "Preliminary findings from a survey of student acceptance and use of e-textbooks in higher education", Allied Academies International Conference: Proceedings of the Academy of Educational Leadership (AEL), Vol. 17, No. 2, pp. 15.

Banditvilai, C. (2016). Enhancing students' language skills through blended learning. Electronic Journal of eLearning, 14(3), 220-229.

Chang, Y-C., Chang, J. S., Chen, H-J., \& Liou, H-C. (2008). An automatic collocation writing assistant for Taiwanese EFL learners: A case of corpus-based NLP technology. Computer Assisted Language Learning, 21(3), 283-299.

Chenoweth, N. A., \& Murday, K. (2003). Measuring student learning in an online French course. CALICO Journal, 20, 285-314.

Chenoweth, N. A., Ushida, E., \& Murday, K. (2006). Student learning in hybrid French and Spanish courses: An overview of language online. CALICO Journal, 24, 115-145.

Ciampa, K. (2012), "Reading in the digital age: Using electronic books as a teaching tool for beginning readers", Canadian Journal of Learning and Technology, Vol. 38, No. 2, p. 1.

Dixon, A. (2012), "From touchstones to touch screens: The evolution of a book lover", Horn Book Magazine, Vol. 88, No. 2, 69-71.

Fidaoui, D., Bahous, R., \& Bacha, N. N. (2010). CALL in Lebanese elementary ESL writing classrooms. Computer Assisted Language Learning, 23(2), 151-168.

Francis, R. \& Susan, J. S. (2013). Engaging with blended learning to improve students' learning outcomes. European Journal of Engineering Education, 4, 359-369.

Green, A., \& Youngs, B. E. (2001). Using the web in elementary French and German courses: Quantitative and qualitative study results. CALICO Journal, 19, 89-123.

Grgurović, M. (2011). Blended learning in an ESL class: a case study. CALICO Journal, 29(1), 100-117. 
Hidayat, N. (2017). Developing E-Reading Materials for Students at Grade Seven. JEES (Journal of English Educators Society), 2(1), 33-44.

Horne, L.K. (2012), "Apps: A practical approach to trade and co-financed book apps", Publishing Research Quarterly, Vol. 28, No. 1, pp. 17-22.

Huang, Y., Liang, T., Su, Y. and Chen, N. (2012), "Empowering personalized learning with an interactive e-book learning system for elementary school students", Educational Technology Research and Development, Vol. 60, No. 4, pp. 703-722.

Huang, Y. N., \& Hong, Z. R. (2015). The effects of a flipped English classroom intervention

on students' information and communication technology and English reading comprehension. Educational Technology Research and Development, 1-19.

Hung, H. T. (2015) Flipping the classroom for English language learners to foster active learning, Computer Assisted Language Learning, 28(1), 81-96.

Lim, D. H. \& Morris, M. L. (2009). Learner and instructional factors influencing learning outcomes within a blended learning environment. Educational Technology Society, 12(4), 282-293.

Liou, H.-C., Yang, P.-C., \& Chang, J. S. (2012). Language supports for journal abstract writing across disciplines. Journal of Computer-assisted Learning, 28(4), 322-335.

Liunokas, Y. (2019). The Use of Think, Pair And Share (TPS) Strategy in Teaching Reading Skill. IDEAS: Journal on English Language Teaching and Learning, Linguistics and Literature, 7(2). doi:https://doi.org/10.24256/ideas.v7i2.1020

Rieders, W. (2011). "ATG special report: Looking beyond e-textbooks and tapping into the personal learning experience", Against The Grain, Vol. 23, No. 3, pp. 42-44.

Romeo, K. (2008). A web-based listening methodology for studying relative clause acquisition. Computer Assisted Language Learning, 21(1), 51-66.

Scida, E. E., \& Saury, E. R. (2006). Hybrid courses and their impact on student and classroom performance: A case study at the University of Virginia. CALICO Journal, 23, 517-531.

Simpson, M. \& Anderson, B. (2009). Redesigning initial teacher education. In E. Stacey \& P. Gerbic(Eds.), Effective blended learning practices. Evidence-based perspectives in ICT-facilitated education,(pp. 62-78).

Stracke, E. (2007). A road to understanding: A qualitative study into why learners drop out of a blended language learning (BLL) environment. ReCALL, 19, 57-78.

Sun, L. (2014). Investigating the effectiveness of Moodle-based blended learning in a college English course. International Journal of Information Technology and Management, 13(1), 83-94.

Tonkery, D. (2010), "The iPad and its possible impact on publishers and libraries", Searcher, Vol. 18, No. 8, pp. 39-42.

Tsai, Y., \& Talley, P. (2014). The effect of a course management system (CMS)-supported strategy instruction on EFL reading comprehension and strategy use. Computer Assisted Language Learning, 27(5), 422-438.

Wichadee, S. (2017). A Development of the Blended Learning Model Using Edmodo for Maximizing Students' Oral Proficiency and Motivation. International Journal of Emerging Technologies in Learning, 12(2), 137-154. 
Yang, Y., Gamble, J., Hung, Y., \& Lin, T. (2014). An online adaptive learning environment for critical thinking infused English literacy instruction. British Journal of Educational Technology, 45(4), 723-747.

\section{Appendix 1. The Design of the Product}

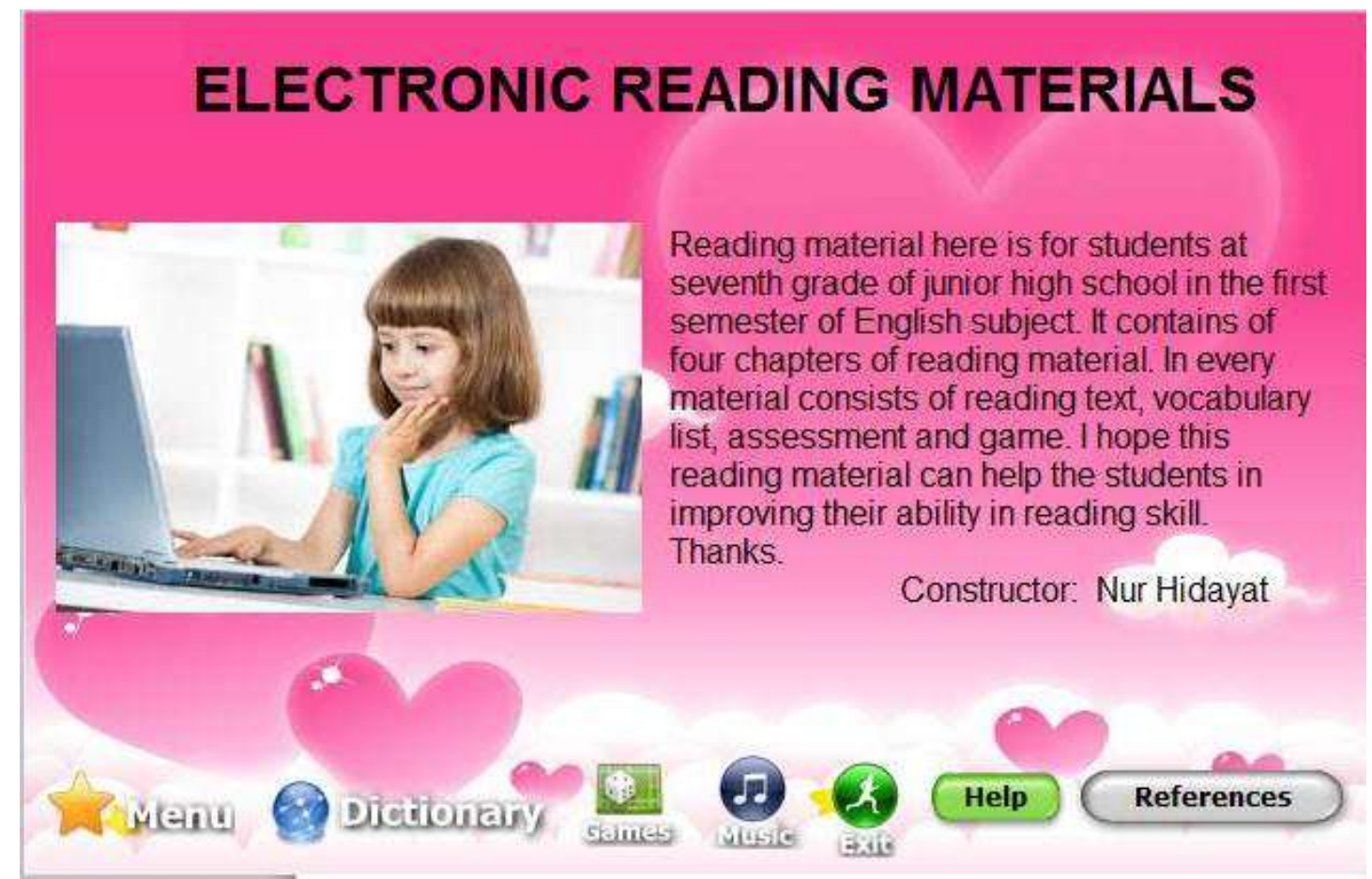

\section{CHAPTER 2}

Reading Material

(-) Bxereise 


\section{GAMES}

Game 1

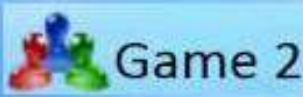

C) Game 3

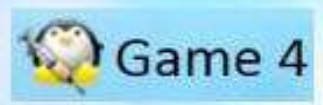

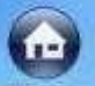

Haine:

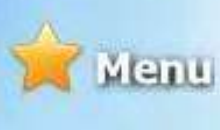

Dickionary 


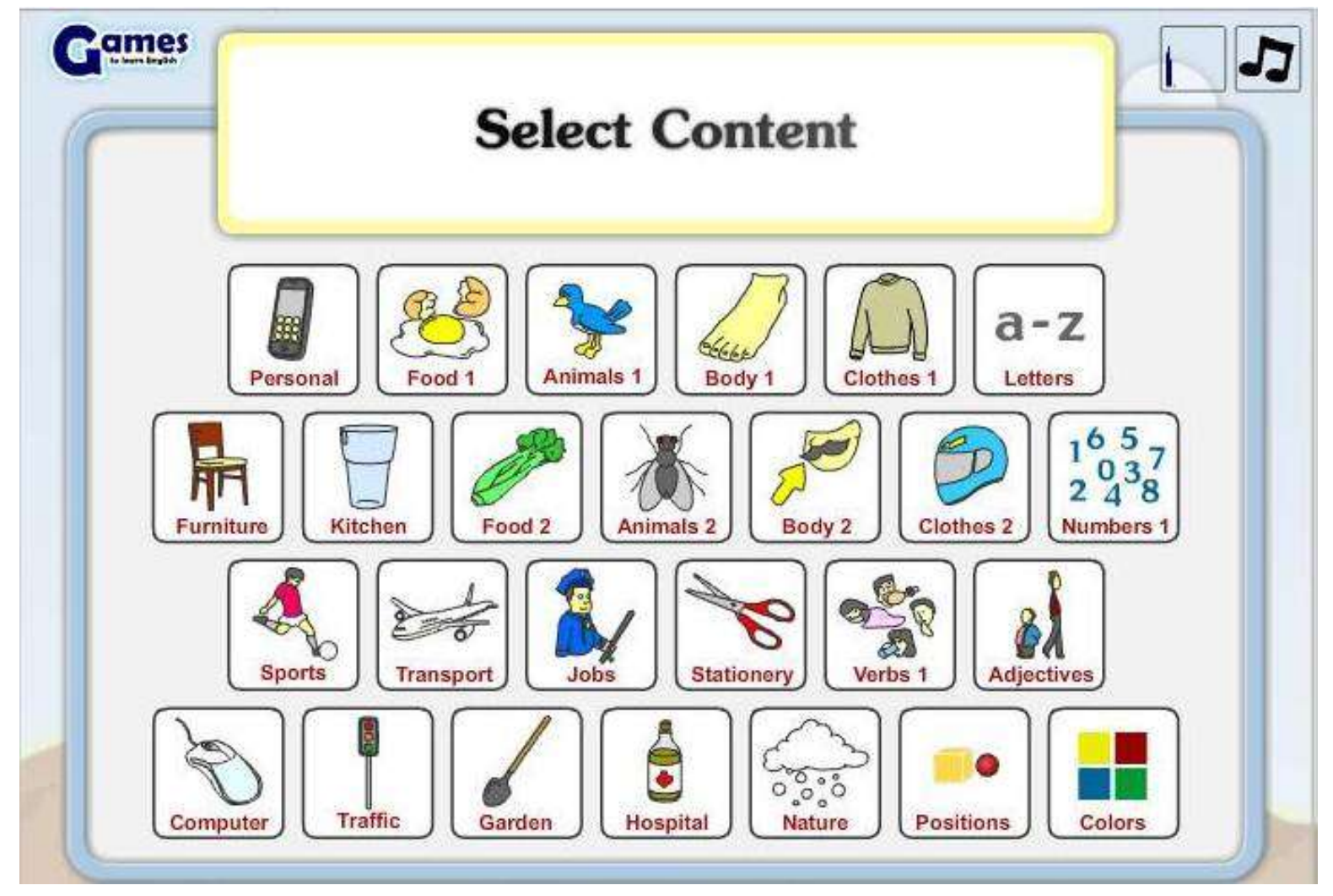

\section{What is this video about?}

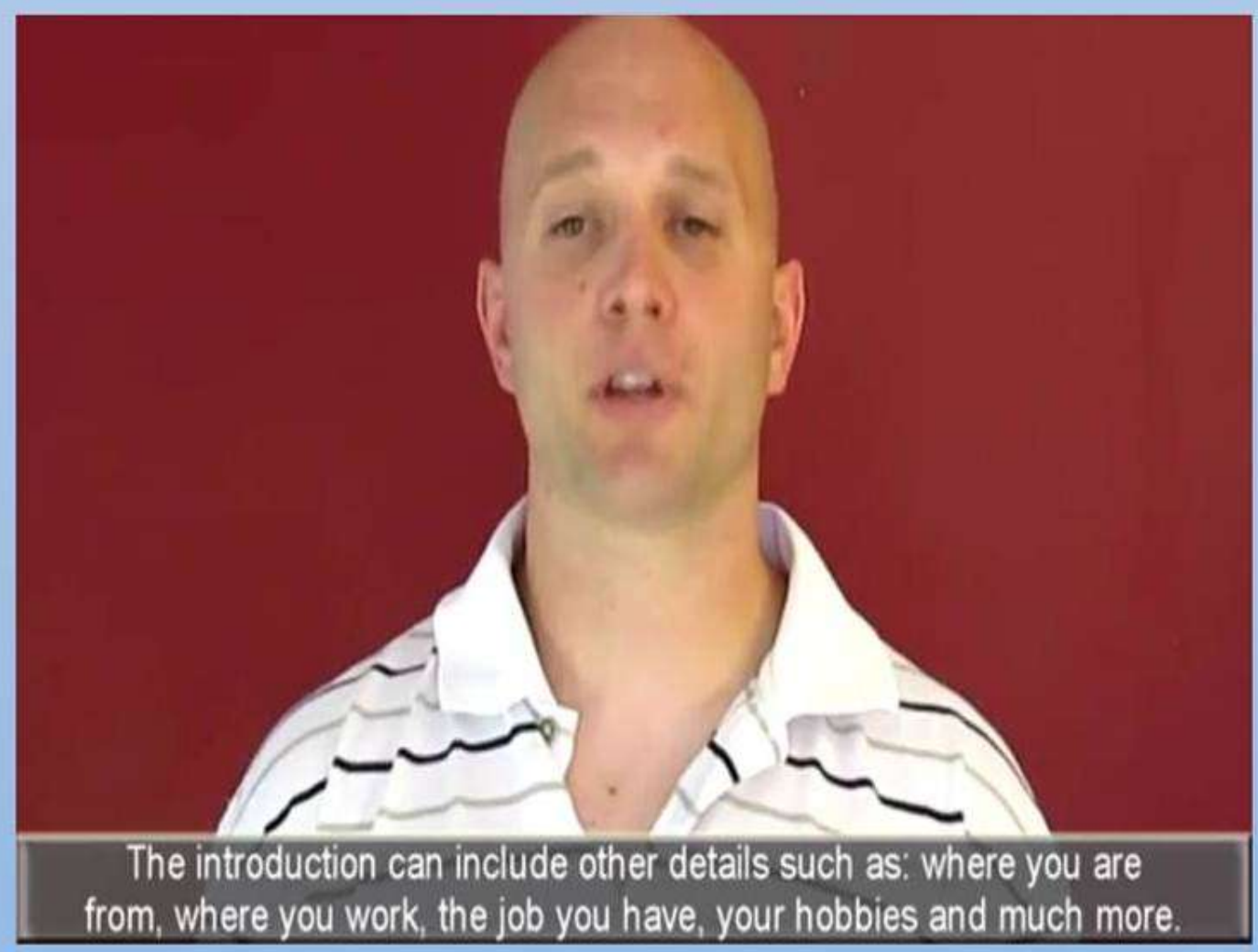

